Key words: personal well-being, personal self-efficacy and harmony, professional competence and self-realization, professional-organizational motivation, professional development and achievements

УДК 159.9-047.22:616-051:373.2

В. М. ВРОНСЬКА

DOI: https://doi.org/10.35619/prap_rv.vi12.44

\title{
ОСОБЛИВОСТІ ПСИХОЛОГІЧНОЇ КОМПЕТЕНТНОСТІ МЕДИЧНОЇ СЕСТРИ ДОШКІЛЬНОГО НАВЧАЛЬНОГО ЗАКЛАДУ
}

На даний час дуже актуальною є проблема збереження та зміцнення здоров'я дітей. Важливу роль при иьому відіграють медичні сестри дошкільних навчальних закладів (далі- ДНЗ). Їм недостатньо мати лише фахову підготовку, медичні сестри ДНЗ повинні мати сформовану психологічну компетентність (відповідно до характеру роботи у даному закладі). Автором проаналізовано особливості вимог до діяльності медичної сестри, починаючи від запровадження иієі професії $і$ до сучасних вимог до діяльності медичної сестри дошкільного навчального закладу зокрема.

Ключові слова: здоров'я, медичні сестри дошкільних навчальних закладів, компетентність, комунікація, робота з вихованцями, робота з батьками, психологічна компетентність.

В это время очень актуальной есть проблема сохранения и укрепления здоровья детей. Важную роль при этом играют медиииские сестры дошкольных учебных заведений (дальше - ДУЗ). Им недостаточно иметь только специальную підготовку, медицинские сестры ДУЗ должны кметь сформированную психологическую компетентность (в соответствии с особенностями работы в данном заведении). Автором проанализировань особенности тренований $\kappa$ деятельности медицинской сестры, начиная от зарождения этой профессии и до современных тренований к деятельности медицинской сестры ДУЗ в часности.

Ключевые слова: здоровъе, медиинские сестры дошкольных учебных заведений, компетентность, коммуникаџия, работа с воспитанниками, работа с родителями; психологическая компетентность.

Постановка проблеми. Батьки в дошкільні навчальні заклади віддають найдорожче власних дітей. Тому, варто піклуватися про збереження та зміцнення здоров'я вихованців. Крім вихователів, це завдання вирішують медичні сестри ДНЗ, які повинні бути готові до роботи в освітніх закладах і мати не лише професійно важливі якості, а і сформовану психологічну компетентність. Тому, своїм завданням вбачаємо висвітлення особливостей психологічної компетентності медичних сестер дошкільних закладів, які позитивно впливають на ефективність виконання їхніх посадових обов’язків. Аналіз становлення уявлень про фахово-важливі якості медичної сестри ДНЗ.

Аналіз останніх досліджень і публікацій. Вчені враховують особливості та важливість надання медичної допомоги дітям. С.Ю.Кокотова акцентує увагу на тому, що психопрофілактичній і просвітницькій роботі з лікарями-педіатрами потрібно приділяти значну увагу, тоді їхнє ставлення до цієї роботи та участь в ній суттєво вплине на їі результат. «Зовнішнє професійне середовище вимагає надмірної емоційної напруженості при виконанні професійних обов'язків лікаря-педіатра, що у ракурсі постійного переживання стресової напруги може призвести до емоційного вигорання, певних мотиваційних викривлень» [3, с. 4]. На взаємозв'язок комунікативної взаємодії і мотивації медиків до виконання професійної діяльності вказував І. С. Сук і зазначав: «питання психологічної несумісності лікаря і хворого не допустиме» [7, с.48].

Однак питання підготовки медичних сестер, для освітніх закладів досі не привернуло належної уваги. Ціла низка спеціальних знань та умінь, потрібних для лікування й догляду за хворими в освітньому закладі не будуть затребуваними, але з іншого боку, набагато вищими стають вимоги іншого характеру. Зокрема, ширшим і детальнішим та набагато менш формалізованим є коло комунікативної взаємодії медичних сестри. До нього входять не лише діти, але й всі без винятку працівники закладу. Широта й різноманітність характеру фахового спілкування медичної сестри ДНЗ пояснюється таким чинником, як різноманітність їі фахових функцій, до яких входять не лише планові профілактичні заходи що стосуються саме дітей, але й низка дій щодо контролю за санітарним станом всього закладу та харчуванням дітей. Ефективне здійснення гігієнічноконтролюючих функції за роботою технічного персоналу та педагогічного колективу передбачає уміння подати свої вимоги у індивідуалізованій і не надто офіційній формі, а це у свою чергу

Випуск 12, 2019. Збірник наукових праць РДГУ 
передбачає високий рівень комунікативної компетентності медичної сестри (на що їх в медичному коледжі, зокрема, не націлювали).

Характер спілкування з вихованцями ДНЗ також вимагає неабиякої гнучкості, оскільки не лише процедура щеплення, а й навіть зважування на вагах, тощо, може викликати у малої дитини переляк. Тому вміння заспокоїти дітей, створити доброзичливу атмосферу, доступно пояснити безпечність, потрібність та нешкідливість виконуваних процедур, спілкуватися з дитиною відповідно до її характеру та віку, потребує певного рівня засвоєння психотерапевтичних навичок. Спілкування 3 батьками вихованців також $є$ індивідуалізованим та доволі складним. Крім того, будучи єдиним медиком у своєму закладі, медична сестра виконує також просвітницькі та консультативні функції щодо збереження та покращення здоров'я як дітей, так і співробітників. Таким чином, широта й різноманітність фахових функцій і пов'язана з цим необхідність мати добре розвинені комунікативні навички та організаційні уміння є причиною того, що медичні працівники нерідко виявляються не готовими до роботи 3 дошкільниками. Різноплановість та високий рівень комунікативних $\mathrm{i}$ організаційних навичок, необхідних для автономної роботи, якою по суті є праця медсестри ДНЗ, передбачає потребу у особистісному вдосконаленні даних фахівців. За таких умов актуальною $\epsilon$ проблема формування психологічної компетентності медичних працівників дошкільних навчальних закладів у системі післядипломної освіти. Соціально-психологічні аспекти підготовки медичних сестер, а також питання формування їхніх професійно значущих якостей широко представлене в літературі з теорії та практики педагогіки і психології, проте специфіка роботи медичної сестри дошкільного навчального закладу в них майже не висвітлена.

За час навчання у медичних коледжах медсестри проходять вишкіл, необхідний для роботи у лікувальному закладі, де від них вимагається передусім високий рівень саме виконавських навичок роботи під постійним керівництвом лікаря. Натомість, медична сестра ДНЗ контактує з лікарем не часто, тому специфіка її роботи вимагає сформованості навичок фахової автономності, високого рівня самоорганізації та психологічної компетентності. Професійними обов'язками медичних сестер ДНЗ. визначаються Порядком медичного обслуговування дітей, згідно якого вони забезпечують організацію роботи медичного кабінету. Крім того, значну частину робочого часу вони мусять відводити на оформлення та ведення медичної документації, а також, контролювати санітарногігієнічний стан свого закладу, взаємодіючи практично з усіма його співробітниками. Медичні сестри ДНЗ повинні знати основи дитячої психології, зокрема психологічні особливості дітей дошкільного віку, нові психолого-педагогічні підходи, працювати над знаходженням нових методів підвищення ефективної взаємодії медпрацівників і вихованців з метою збереження і зміцнення їх здоров'я. Це сприятиме кращому вирішенню завдань, покладених на медпрацівників дошкільних навчальних закладів. Для вирішення цих завдань не достатньо лише суто медичної компетентності медсестер, Нами розроблено Програму курсів підвищення кваліфікації медичних сестер дошкільних навчальних закладів, в основі якої покладено принцип саморозвитку особистості та культурологічна спрямованість навчально-виховного процесу дошкільних навчальних закладів.

Сутність професії медика виходить із гуманних відносин, бо не можна любити професію медика не люблячи людину. Медик повинен відчувати біль і переживання іншої людини як свої власні. Це допоможе зрозуміти стан хворої дитини і розділити з нею ії переживання, що має велике значення для захворілого дошкільника. Адже для будь-якої людини дуже важливо, щоб ії зрозуміли. «В основі нормальної професійної діяльності медичного працівника лежить мораль - унікальне всеохоплююче явище суспільного життя, яке регулює людське спілкування й поведінку у будь-якій сфері життя і діяльності... Ці якості розглядаються не просто як якості, що заслуговують уваги особистості в цілому, а як свідчення його професіоналізму» $[4$, с. 48]. «Підгрунтям успішної професійної діяльності лікаря вважають моральність. Адже моральні якості є показником стійкості і міцності сформованих вмінь, навичок, здібностей, у тому числі й професійних. Позбавлений моральності, медпрацівник втрачає основні важелі у здійсненні процесу самовдосконалення. Моральні переконання, моральні якості (чесність, почуття відповідальності, совість тощо), моральні звички, здібності та дії виконують вищу регулюючу функцію стосовно процесу формування професійних навичок і вмінь у діяльності медичного працівника. Високий рівень моральної культури дозволяє йому не тільки свідомо та систематично долати негативні риси свого характеру, але й у вищій мірі інтенсифікувати свою професійну працю. Медик повинен заслужити довіру у пацієнта. Тільки завдяки довірливим відносинам, бажаний результат наступить швидше» [5, с. 5]. Ще в XIXст. відомий лікар Г. А. Захар’їн твердив: «Немає необхідності пояснювати, в якому важкому становищі знаходиться лікар, до якого не мають довіри; ще важчою є ситуація хворого, вимушеного лікуватися у лікаря до якого немає довіри» [5, с. 5]. «Для налагодження довірливих стосунків важливим є перше враження, яке виникає у хворого при зустрічі з медпрацівником: це перш за все міміка, жестикуляція,

Випуск 12, 2019 Збірник наукових праць РДГУ. 
інтонація голосу, вираз обличчя, що може бути зумовленим попередньою ситуацією і не стосуватися пацієнта, а також і зовнішній вигляд: якщо хворий бачить медика неохайного і некоректного, то він втрачає в нього віру, вважаючи, що людина, яка нездатна турбуватися про себе, не може турбуватися про інших. Різні відхилення в мімічних проявах і в зовнішньому вигляді пацієнти та їх рідні швидше готові пробачити тим медичним працівникам, які їм знайомі і до яких відчувають довіру» [6, с. 10]. Тому у взаємодії з вихованцями дошкільних закладів слід перш за все дбати про професійну культуру медичної сестри.

За результатами спостережень за діяльністю медичних сестер ДНЗ під час практики і у міжкурсовий період можна стверджувати, що медичні працівники по-різному ставляться до проблем хворих. В. Г. Косенко, Л.Ф. Смоленко, Т.А.Чебуракова стверджують: «Медичний працівник, який тільки розпочинає власну професійну діяльність, зазвичай, ближчий до психології хворого. Він краще вживається в те, як хворий переносить біль у зв'язку із початком захворювання. Цьому сприяє в числі інших також мотивація, що привела молодих людей до медичної професії. Значна частина тих, що обрали медицину мотивує власний вибір цієї професії тим, що самі вони колись перенесли серйозне захворювання або бачили в інших, знаходячись у лікарні, чи зустрічалися з ним у своїх близьких і прийняли рішення допомагати стражденним, взяти участь у вивченні причин захворювання, їх профілактики. Тi, які прийшли в медицину і охорону здоров'я тільки внаслідок співчуття - а таких більшість, - при зіткненні з медичним середовищем переживають деяке розчарування» [6, с.11]. «В медичній етиці існують незникаючі принципи, зумовлені гуманізмом медичної професії. Звернення до особистості хворого - одне з головних завдань сучасного лікування, тому і лікарі, і медичні сестри повинні враховувати індивідуально-психологічні особливості пацієнта.

Враховувати душевний світ пацієнта, сформульований ще Гіппократом принцип «лікувати хворого, а не хворобу» [5, с.3 ] - у практичній медицині й досі лишається значною мірою декларативним. Віддаленість лікування від конкретної особи пацієнта, виконання лікарських обов'язків в умовах мінімального ознайомлення з індивідуальними особливостями суб'єкта, його особливим складом відносин, сприйняття й очікувань, пов'язаних із захворюванням, на жаль, надто типові для сьогоднішньої лікувальної практики. Надзвичайна складність сучасних діагностичних і лікувальних засобів, а також пов'язане з цим поширення вузьких за фахом спеціалізацій медиків, «індустріалізація» охорони здоров'я, поставленість лікування „на потік” докорінно змінили характер відносин у системі «хворий-лікар». «Стає зрозуміло, що інституціоналізація психологічної допомоги покликала до життя поряд із паралельним розвитком традиційної медичної та релігійної допомоги два принципово нових види послуг та професій (соціальна допомога - сприяння та психологічна допомога - консультування) і трансформувала традиційне пасторське опікування до нової форми релігійного наставництва - духовне допомога на основі Нового завіту, але поза церквою» [1; с.13-14]. Згадаємо, що перші медсестри були монахинями, вони доглядали за хворими при монастирських лікарнях. Не заглиблюючись в деталі, проаналізуємо особливості виникнення професії медичної сестри. Відомості щодо історії розвитку сестринської справи свідчать, що підготовка медсестер та їхня активна участь у лікувальному процесі розгорнулася з середини ХІХ століття; пізніше - 3 ініціативи М. І. Пирогова; значною була роль медичних сестер у час Кримської війни (1853-1856); у той же період розгорнула підготовку кадрів середнього і молодшого медперсоналу відома англійка Флоренс Найтінгел, (1855p), згодом - общини сестер милосердя створюють у Москві, Кронштадті, Харкові, Тифлісі тощо. Внесок у справу забезпечення медичної освіти жінок зробили: М. І. Пирогов, С. П. Боткін - за їх ініціативи було створено Комітет піклування про сестер милосердя. Заборона вступу до вишів жінкам у Росії компенсувалася їхнім навчання у Швейцарії.

1872-1882pp. були створені медичні курси для жінок при Петербурзькій медико-хірургічній академії.

1879 р. - відкрито жіночу фельдшерську школу у Москві, а 1882p. - у Петербурзі.

1907 р. - засновано Російське товариство Червоного Хреста.

Хоча, на етапі запровадження професії медсестри, від самого початку зародження медсестринства, питання формування їхньої психологічної компетентності медичних сестер не висвітлювалися, однак, можемо стверджувати, що ці якості завжди бралися до уваги, про що свідчить тодішня назва професії - сестра милосердя. На сучасному рівні розуміння визначення медична психологія, іiі місце, обсяг дотепер дещо по-різному розуміються спеціалістами різних країн. Цілий комплекс загальних і спеціальних психологічних питань, що випливають 3 проблем охорони здоров'я включає предмет медичної психології. «Медичну психологію 3 педагогічною метою поділяють на загальну та спеціальну» [2;c.23-24]. На думку І.С. Вітенка, «клінічна психологія $\epsilon$ логічним «продовженням» загальної психології, але вже в галузі медицини, і складовою частиною медичної психології...У нашій країні традиційно в медичну психологію включають, крім клінічної 
психології, також психогігієну» [2; с.7]. Медичні сестри ДНЗ повинні мати сформовану психологічну компетентність відповідну до характеру роботи у даному закладі. У пацієнта завжди є потреба не лише в медичній, а й у психологічній допомозі, для прикладу, вони ії знаходять у фахівців 3 нетрадиційної медицини. «Існування потягу до незвичного свідчить про постійну, глибоку потребу хворої людини не лише в медичній (ліки, операції), а й психологічній допомозі та підтримці» [5; с.10]. Серед актуальних проблем, що характерні для сучасного суспільства, важливе місце займає проблема збереження та зміцнення здоров'я дітей. Її намагаються вирішити медичні працівники разом з батьками і педагогами. Але, на жаль... саме на роботу з дітьми дошкільного віку у ДНЗ медичних сестер під час навчанні у коледжах не націлювали. Тому, це необхідно здійснювати в системі післядипломної педагогічної освіти. Спостерігаються і нововведення у системі дошкільної освіти, зокрема, змінено кількість штатних одиниць медичних працівників та передбачено нові посади «сестра медична старша; сестра медична, сестра медична 3 дієтичного харчування, сестра медична лікувального кабінету; сестра медична з масажу та сестра з лікувальної фізкультури; сестра медична 3 фізіотерапії та лікування» [4; с.31]. Працівники дошкільного навчального закладу несуть відповідальність за життя, фізичне і психічне здоров'я кожної дитини відповідно до чинного законодавства. Зазвичай медсестра у ДНЗ є єдиним носієм медичних знань!

Висновки та перспективи подальших досліджень. Проаналізувавши особливості професії «медична сестра» можна зрозуміти, що від самого початку засади гуманності та милосердя були основними у сестринській справі. Тому, варто враховувати особливості професійної діяльності медичної сестри дошкільного навчального закладу і пам'ятати про те, що у неї повинна бути сформована психологічна компетентність.

\section{Список використаних джерел} 1996. - 238c.

1. Бондаренко О.Ф. Психологічна допомога особистості / О. Ф. Бондаренко. - Харків: Фоліо,

2. Осснови загальної і медичної психології / І. С Вітенко, Л.М Дутка, Л.Я.Зименковська Київ : Вища школа, 1991. - 270 с.

3. Кокотова С. Ю. Особливості професійної мотивації лікарів-педіатрів/ С.Ю.Кокотова. Луцьк.: Вежа, 2007. - 166 с.

4. Морєва О. Введення до штатних розписів дошкільних навчальних закладів штатних одиниць медичних працівників / О. Морєва // Практика управління дошкільним закладом. - 2011. №2. - C. 30-33.

5. Магазаник Н. А. Искусство общения с больными / Н. А. Магазаник. - Москва: Медицина, 1991. $-110 \mathrm{c}$.

6. Косенко В.Г., Смоленко Л.Ф., Чебуракова Т.А. Медицинская психология для медицинских сестер и фельдшеров. - Ростов-на-Дону, Фенікс, 2002 - 411с.

7. Сук И.С. Врач как личность./И.С.Сук. - Москва: Медицина, 1984. - 61с

\section{References} 1996. -238 s.

1. Bondarenko O.F. Psykholohichna dopomoha osobystosti / O. F. Bondarenko.- Kharkiv: Folio,

2. Osnovy zahalnoyi i medychnoyi psykholohiyi / Vitenko I. S., Dutka L.M., Zym- enkovska L. YA. - Kyyiv: Vyshcha shkola, 1991. - 270 s.

3. Kokotova S. YU. Osoblyvosti profesiynoyi motyvatsiyi likariv-pediatriv/S.YU.Kokotova. Lutsk.: Vezha, 2007. - $166 \mathrm{~s}$.

4. Moryeva O. Vvedennya do shtatnykh rozpysiv doshkilnykh navchal'nykh zakladiv shtatnykh odynyts medychnykh pratsivnykiv / O. Moryeva // Praktyka upravlinnya doshkilnym zakladom. - 2011. №2. - S. 30-33. 5. Mahazanyk N. A. Yskusstvo obshchenyya s bolnymy / N. A. Mahazanyk. Moskva: Medytsyna, 1991. - 110 s. 6. Kosenko V.H., Smolenko L.F., Cheburakova T.A. Medytsynskaya psykholohyya dlya medytsynskykh sester y feldsherov. Rostov-na -Donu, Feniks, 2002 - 411s. 7. Suk Y.S.Vrach kak lychnost./Y.S.Suk. Moskva: Medytsyna, 1984.-61s

\section{V.N. Vronska FEATURES OF PSYCHOLOGICAL COMPETENCE OF MEDICAL SETTLEMENT OF PRE-SCHOOL EDUCATIONAL AGENCY}

At this time there is a very urgent problem of preserving and strengthening the health of children. An important role is played by nurses of preschool educational institutions (hereinafter referred to as preschool educational institutions). However, it was precisely for work at pre-school institutions, when they 
were studying in colleges, they were not targeted. At the same time, according to our researches, the nature of work in preschool educational establishments presents to the nurse essentially other professional requirements. We took into account the peculiarities of the psychological training of future nurses in medical colleges.

The modern regulatory requirements for the activity of a nursing school in pre-school educational institutions are taken into account. It is not enough for them to have only special training, the nurses should be able to shape their psychological competence (in accordance with the peculiarities of work in this institution). The author analyzed the peculiarities of nursing activities for a nurse, ranging from the birth of this profession to modern nursing activities for a nurse's institute in particular.

Key words: health; nurses of pre-school educational institutions; competence; communication; psychological competence.

УДК 159.9- 051

DOI: https://doi.org/10.35619/prap_rv.vi12.45

О. Д. ГЛАВІНСЬКА, Л. О. НОВІК

\section{УСВІДОМЛЕННЯ МАЙБУТНІМИ ПСИХОЛОГАМИ ПРОФЕСІЙНОЇ НАЛЕЖНОСТІ}

У статті розглядається проблема професійного становлення майбутніх психологів. Досліджується феномен уявлення про професію як складний особистісний практичний механізм, який є показником суб'єктивного досвіду, компонентом професійної самосвідомості. Отримані у ході дослідження результати вказують на необхідність здійснення психологічних впливів, спрямованих на розвиток професійних підструктур самосвідомості, а також створення відповідних психологічних умов для оптимізачії процесу формування особистіснозрілого фахівия в умовах навчання у закладах вищої освіти.

Ключові слова: професійне становлення, професійне самовизначення, професійна свідомість, уявлення про професію, майбутні психологи.

Статья посвящена проблеме готовности будущих психологов $к$ профессиональному самоопределению и профессиональному становлению. Исследуется феномен представления о профессии как личностный практический механизм, который выступает показателем субъективного опыта, компонентом профессионального сознания. Полученные в ходе исследования результаты свидетельствуют о необходимости психологического влияния, направленного на развитие профессиональных подструктур сознания, а также создания соответствуюших психологических условий для оптимизации процесса формирования личностно зрелого специалиста 8 условиях обучения в учреждениях высшего образования.

Ключевые слова: профессиональное становлени, профессиональное самоопределение, профессиональное сознание, представление о профессии, будущие психологи.

Постановка наукової проблеми та ії значення. Головними сферами життєдіяльності студентів $\epsilon$ професійне навчання, особистісне зростання та самоствердження, розвиток інтелектуального потенціалу, духовне збагачення, моральне, естетичне та фізичне самовдосконалення. Цей період особистісного становлення характеризується оволодінням усім різноманіттям соціальних ролей дорослої людини: отримання права вибору, набуття певної юридичної та економічної відповідальності, можливість включення в усі види соціальної активності, здобуття вищої освіти та опанування професії. Найважливішою детермінантою ефективності професійної діяльності вважається професійна свідомість фахівця - психологічне утворення, в якому інтегруються професійні цінності, науково-теоретичні знання, програми професійних дій, а також знання людини про себе як про представника певної професії. Саме професійна свідомість акумулює всі ці аспекти, рівні, функції у практичній та теоретичній професійній діяльності майбутнього фахівця.

Професійна належність $€$ результатом тривалого процесу професійного розвитку, який базується на глибокому пізнанні себе, розумінні та усвідомленні вимог бажаної майбутньої професії. При цьому важливим аспектом результативної складової професійної належності є сформованість рівня професійних домагань та адекватна самооцінка. Цей функціональний зв'язок демонструє прагнення в обраній професії досягнути цілей певної складності. Можна стверджувати, що професійні домагання являються якісною характеристикою професійної належності і невід'ємно пов'язані $з$ динамічними показниками успіху як рушійного особистісного еквіваленту. Необхідність 